\title{
Effects of Vegetable Oil Pollution on Aquatic Macroinvertebrate Assemblage in a Freshwater Wetland and Its Use as a Remediation Tool
}

\author{
M. C. Selala • A-M. Botha • A. R. de Klerk • \\ L. P. de Klerk • J. G. Myburgh • M. C. M. Blettler • \\ P. J. Oberholster
}

Received: 5 May 2013 / Accepted: 10 July 2013

(C) Springer Science+Business Media Dordrecht 2013

\begin{abstract}
The occurrence, as well as the environmental fate and impact, of vegetable oil spills in freshwater wetlands have until now been unreported. Thus, the largest global vegetable oil spillage in a freshwater wetland, which occurred at the Con Joubert Bird Sanctuary wetland in 2007, presented an ideal opportunity to evaluate these impacts. Five post-spill sampling sites were selected within the wetland from which a variety of abiotic and biotic samples were collected bimonthly over a period of 12 months. Abiotic variables included the sediment and water column oil concentrations, total nitrogen, total phosphorous, biochemical
\end{abstract}

M. C. Selala · J. G. Myburgh · P. J. Oberholster $(\bowtie)$

Department of Paraclinical Sciences, Faculty of Veterinary

Science, University of Pretoria-Onderstepoort,

Private Bag x04, Onderstepoort, Pretoria 0110, South Africa

e-mail: poberholster@csir.co.za

A.-M. Botha $\cdot$ A. R. de Klerk

Department of Genetics, University of Stellenbosch,

Matieland, Stellenbosch 7601, South Africa

A. R. de Klerk • L. P. de Klerk • P. J. Oberholster

CSIR Natural Resources and the Environment,

P.O. Box 395, Pretoria 0001, South Africa

M. C. M. Blettler

National Institute of Limnology (INALI; CONICET-UNL),

Ciudad Universitaria 3000, Santa Fe, Argentina

P. J. Oberholster

CSIR Natural Resources and the Environment,

P.O. Box 320, Stellenbosch 7599, South Africa oxygen demand (BOD), silica, chlorophyll $a$, as well as in situ measurements of $\mathrm{pH}$, electrical conductivity, and dissolved oxygen. Aquatic macroinvertebrates were chosen as biotic indicators in the study field due to their wide applicability as water quality indicators and were thus collected at each site. Spatial and temporal changes in total nitrogen, total phosphorous, and chlorophyll $a$ concentrations as well as changes in $\mathrm{pH}$ were observed. The oil spillage also resulted in an increase in tolerant macroinvertebrate taxa, mainly Chironomidae and Psychodidae, at the sites closest to the source of the spillage. These two taxa, and to a lesser extent, Syrphidae, were identified as potentially useful indicators to determine the extent of vegetable oil contamination within a freshwater wetland. Furthermore, monitoring of these indicator taxa can be a useful management tool to determine the recovery of freshwater wetlands after vegetable oil spills. In the study, a static battery of bioassays of different biotic trophic levels was also employed to determine the adverse effects of the spilled vegetable oil on the biotic environment. It was evident from the result of the static battery of bioassay that adverse effects of the sunflower oil differ between trophic levels. The latter was in relationship with the data obtained from the field macroinvertebrate study, indicating that certain macroinvertebrate families were more tolerant to the adverse effects of sunflower oil than other families.

Keywords Freshwater wetland - Sunflower oil spill . Static battery of bioassays $\cdot$ Chironomidae $\cdot$ Psychodidae 


\section{Introduction}

Aquatic macroinvertebrates can be used to monitor aquatic environments because they are in constant contact with the surrounding aquatic environment (Chutter 1998; De la Rey et al. 2004). They are useful for such tasks due to their visibility to the naked eye, ease of identification, rapid life cycle, and position in the food chain (Dickens and Graham 2002). Generally, aquatic macroinvertebrates such as Dytiscidae, Elmidae, Hirudinae, Belostomatidae, Oligochaeta, and Chironomidae are responsive to quick changes in water quality with respect to anthropogenic pollution (Mousavi et al. 2003; Rainio and Niemela 2003; Arimoro et al. 2007; Oberholster et al. 2009). Aquatic macroinvertebrates have relatively short life cycles ( $\mathrm{Wu}$ et al. 2004; Takahashi et al. 2008), and changes in the composition and structure of their communities are dependent on water quality (Marques and Barbosa 2001; Nazarova et al. 2008). Most importantly, it is known that aquatic macroinvertebrates are sensitive to oil spills, and the effect depends on the type of hydrocarbon-sensitive species present in the aquatic system (Gesteira et al. 2003; Oberholster et al. 2010). According to Cairns et al. (1993), only biological specimens can determine the effects of chemical stressors in an ecosystem. These organisms respond differently to the physicochemical condition of the water source. A chain of various biological and physicochemical links could be applied to diversify the ecological spectrum using sensitive bio-indicator species (Tripole et al. 2006).

A battery of bioassays is short-term aquatic toxicity tests which are used to determine the adverse effects of pollutants in sediment and the water column (Clément et al. 2004; Oberholster et al. 2005). Van Dam et al. (1998) suggested that both toxicity bioassays and monitoring techniques should be applied in a wetland risk assessment program to determine degradation. According to Blaise et al. (2004) and Oberholster et al. (2005), bioassays are highly rated in oil spill remediation programs to provide operational guidance because it can identify potential detrimental effects from applications and provide a means of quantifying treatment success.

When oil is spilled in an aquatic environment, it can be transformed through various biological, chemical, and physical weathering processes. These processes can then change the behavior, composition, exposure routes, and toxicity of the oil (USDOC and NOAA 1996). The biodegradation of oil is affected by dissolved oxygen, $\mathrm{pH}$, occurrences of nutrients in the proper proportions, soil types, the dispersal of oil, the type of oil, as well as the concentration of undissociated fatty acids in the water (Cornish et al. 1993; Rigger 1997).

Although there is a lot of information available on the effects of an oil spill on marine, river, and coastal marsh environments (e.g., Zoun et al. 1991; Mudge et al. 1993; Mudge 1995), not much is known about the effect of such a spill on a freshwater wetland. In addition, the effect of oil contamination within an aquatic environment is difficult to evaluate because of the unavailability of data prior to a spillage (Bury 1972; Oberholster et al. 2010), but it is known that an oil spill can cause severe damage to sensitive aquatic organisms and ecosystems (Mudge 1995). There is also a known delay between exposure during the oil spill and the expression of adverse effects. This is mainly depending on the toxic constituents within the oil in question or due to the formation of toxic by-products during degradation within the environment (USEPA 1997). According to Poulton et al. (1997), oil spills in rivers are known to be associated with an increase in tolerant aquatic macroinvertebrates (e.g., Chironomidae and Oligochaeta). The reduction of sensitive taxa such as Trichoptera and Plecoptera in response to such a spill has also been observed and is likely to persist for a considerable period of time (Lytle and Peckarsky 2001). Different types of vegetable oils and fats, namely, soya bean, rapeseed, palms, and coconut, show similar characteristics in aquatic environments (Frink 1994). When these oils enter an aquatic environment, their fatty acid constituent enables it, depending on the prevailing physicochemical properties, to either float on top of the water surface and become solubilised, emulsify in the water column, or settle on the sediment (USEPA 1997).

Currently, information relating to the effects of vegetable oil spills on freshwater wetlands including their associated biota is very limited. Thus, the aim of this study was to determine the temporal and spatial changes of aquatic macroinvertebrates and selected abiotic variables at various sites within a wetland at the Con Joubert Bird Sanctuary after a sunflower oil spill. A static battery of bioassays on different biotic trophic levels was also employed to determine the adverse effects of the spilled vegetable oil on the biotic environment and its relationship with vegetable oiltolerant macroinvertebrates in the study field. Through the information generated by this study, the authors hope to improve the current knowledge base on the aquatic 
environmental effects of vegetable oil spills in freshwater wetlands.

\section{Materials and Methods}

\subsection{Study Area}

This study focused on a wetland, approximately 25 ha in size, in the Con Joubert Bird Sanctuary (26 $11^{\prime} 20^{\prime \prime}$ S, $27^{\circ} 41^{\prime} 03^{\prime \prime}$ E) within the Randfontein Municipality, South Africa. In the beginning of September 2007, a sunflower oil storage tank collapsed, causing a spill of 250 ton of sunflower oil. The spilled oil flowed into the wetland via a water drainage system. Five sampling sites were chosen to be representatives of the entire wetland. The location of the study area, as well as the respective sampling sites, is presented in Fig. 1. Site 1 was located on the eastern side of the wetland, close to the inflow of the water drainage system from where the sunflower oil spillage occurred. The marginal vegetation at this site consists mainly of Typha capensis, Phragmites australis, and Lemna sp. Polymerized oil was observed floating on the water surface at this site. Site 2 was located in the southern part of the wetland and is mainly characterized by Juncus effuses, Persicaria decipiens, Schoenoplectus brachyceras, Azolla pinnata, and Lemna gibba. Sites 3 to 5 were located on the western side of the wetland and consisted mainly of A. pinnata, J. effuses, T. capensis, L. gibba, and P. decipiens. The substrate of all five sampling sites was mainly made up of clay and organic material. The average water depth over the study period at all of the sites was approximately $20 \mathrm{~cm}$. Sampling was conducted over a period of 1 year including the following months: October 2008 and January, April, June, August, and October 2009.

\subsection{Water and Sediment}

Various in situ measurements such as $\mathrm{pH}$, electrical conductivity, and dissolved oxygen were measured in the field using a $\mathrm{Hach}^{\mathrm{TM}}$ sension 156 portable multiparameter meter. Duplicate water samples were collected at the surface and at the bottom using a grab bottle sampler. The grab bottle sampler was cleaned with alcohol after sample collection at each site to prevent a possible cross-contamination of oil. Both the surface and bottom grab bottle samples were pooled together to form one integrated sample and used to fill three precleaned containers for chemical analyses and the static battery of bioassays. These containers were filled and kept in a cold and dark environment to minimize risks of chemical and biological processes occurring in the bottles while in transit to the laboratory. Various chemical parameters, including total phosphate (expressed as $\mathrm{PO}_{4}{ }^{3-}$ ), total nitrogen (expressed as the sum of $\mathrm{NH}_{4}{ }^{+}, \mathrm{NO}_{3}{ }^{-}$, and $\mathrm{NO}_{2}{ }^{-}$), and silica concentrations, were determined in each water sample. Total nitrogen and total phosphate concentrations were measured using the most appropriate spectrophotometric methods (APHA, AWWA, and WPCF 1992). The determination of biological/biochemical oxygen demand (BOD) was determined using a standard method by incubating the samples at $20{ }^{\circ} \mathrm{C}$ in the dark for 5 days. The amount of dissolved oxygen was measured as the consumption of oxygen after a period of 5 days in the sample. The difference between the initial and final concentration of oxygen was then calculated (Hauer and Lamberti 2006). Chlorophyll $a$ concentrations were measured using sub-samples of the integrated water samples collected. Chlorophyll was extracted using $80 \%$ acetone after an overnight incubation. The chlorophyll $a$ concentrations were determined spectrophotometrically at 664- and 647-nm wavelengths, respectively, according to Porra et al. (1989). Triplicate sediment samples (upper $5 \mathrm{~cm}$ ) were taken randomly at each sampling site using a Perspex sediment corer $(5 \mathrm{~cm}$ in diameter). This was done in order to determine the spatial extent of oil contamination within the sediment profile (Oberholster et al. 2005). The sediment corer was cleaned with alcohol after each site was sampled to prevent any oil cross-contamination. Sunflower oil in the sediment and the water column was determined by using the US Environmental Protection Agency Gravimetric Method 413.1 (Code of Federal Regulations, Part 136, 1994). This gravimetric method measures oil directly since only soluble intermediate constituents (e.g., free fatty acids and glycerol) of vegetable oil are toxic to organisms. These chemical residues impact organisms by accumulating in the cellular membranes and disruption of cellular and tissues functionality (French-McCay 2002; Wincele et al. 2004).

\subsection{Aquatic Macroinvertebrates}

Aquatic macroinvertebrates were collected using a sweep net $(300 \times 300-\mathrm{mm}$ frame, $1,000-\mu \mathrm{m}$ mesh), which included sampling all of the available biotopes 


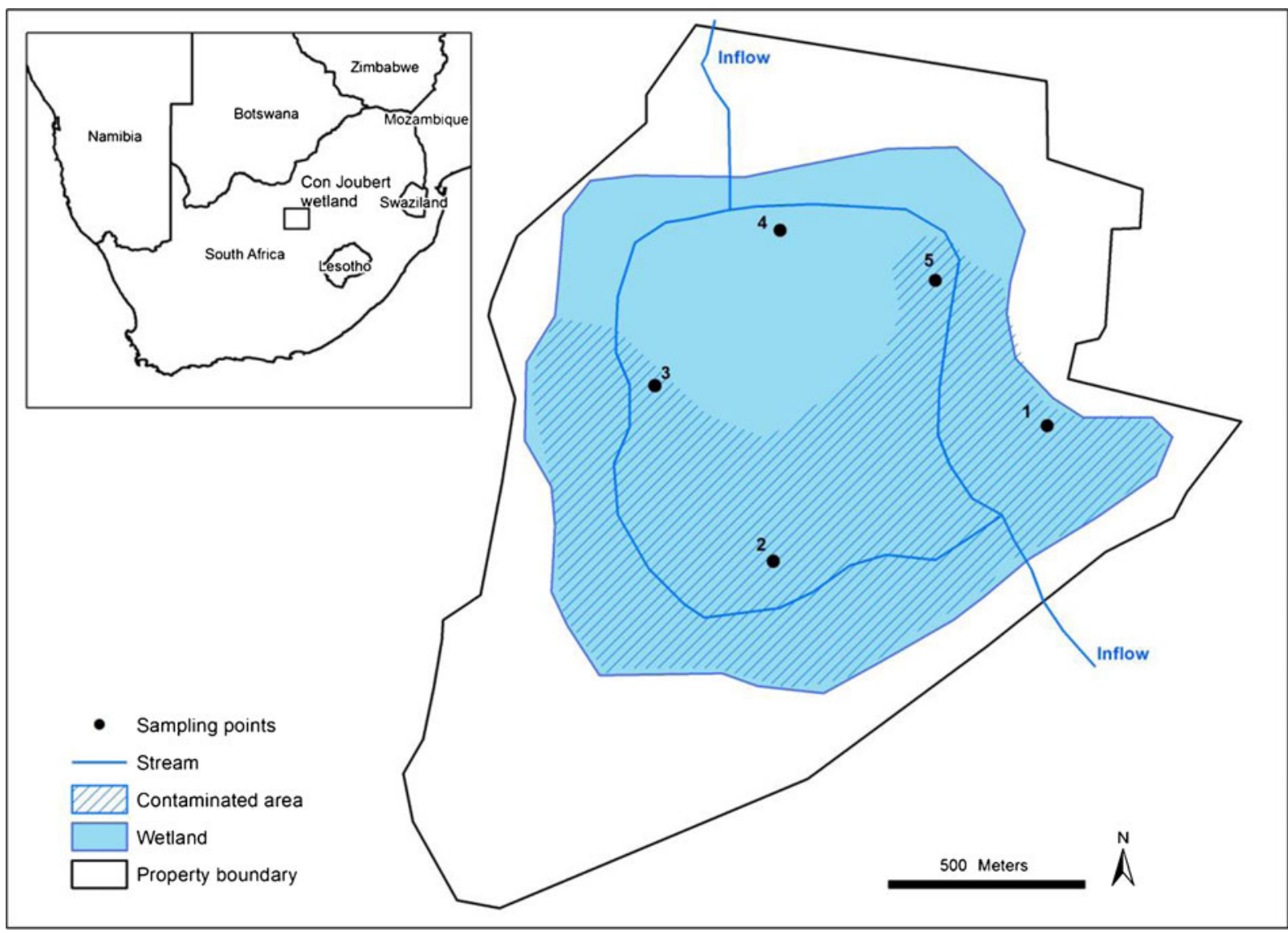

Fig. 1 Map of the Con Joubert Bird sanctuary wetland showing the location of the five sampling sites and the position of the inflowing storm water inlets. Inset shows the location of the map

(MPCA 2008; de Klerk and Wepener 2011). The macroinvertebrate samples were immediately preserved in $70 \%$ ethanol and later sorted using a $75-\mu \mathrm{m}$ mesh sieve. The macroinvertebrates were identified to family level according to Merritt and Cummins (1996) and Thorp and Covich (2001) by randomly sub-sampling a tenth of the total sample under a dissection microscope at $\times 20$ magnification. These samples were then enumerated. The macroinvertebrates collected within a subsample of the 5-cm-diameter sediment core sample were also removed, identified, and enumerated.

\subsection{Battery of Bioassays to Determine the Adverse Effects of Vegetable Oil on the Biotic Wetland} Environment

The battery of bioassays used in this study included three different trophic levels of organisms which were area in South Africa. The visually observed extent of the oil pollution after the spillage occurred is also indicated

developed with the following criteria in mind: low cost, organisms and suppliers locally available, sensitive to a wide spectrum of organic compounds, reproducible, and representative of more than two trophic levels (producers, grazers, and filter feeders). All bioassays were performed on a 2-monthly basis after collection of water samples from the selected five sampling sites. The following static battery of bioassay methods was employed with undiluted wetland water: (1) algal phytotoxicity and growth inhibition bioassay (Slabbert 2004), (2) Daphnia pulex zooplankton bioassay (Slabbert 2004), (3) Physa acuta snail bioassay (Musee et al. 2010), and (4) Spirodela punctata bioassay (Vujević et al., 2000).

\subsection{Statistical Analyses}

Univariate statistics such as Shannon's diversity index (Shannon 1948) was used to determine the aquatic 
macroinvertebrate diversity at each site with the software program PRIMER version 6.0 (Clarke and Gorley 2006). Both species richness and equitability components are incorporated in the Shannon diversity index. Thus, to obtain a measure of species richness based on a presumed linear relation between the numbers of species and logarithm of the number of individuals, Margalef's index (d) was also used (Margalef 1951). Multivariate statistics, such as a redundancy analysis plot, was constructed to determine the relationship between the macroinvertebrate community structures identified at each site and the respective environmental variables measured. These plots were expressed two-dimensionally where distances among them reflect their relative similarity or dissimilarity. In an ordination plot, the arrows may be used to indicate the direction of the steepest increase, as well as if any correlation between variables exists depending on whether the angles between them are acute or not. Significant spatial differences in the concentrations of the selected abiotic variables between different sites were determined using a one-way analysis of variance (ANOVA). Significance was assumed as a probability level of $p \leq 0.05$. The temporal data were also subjected to a one-way ANOVA to determine significantly $(p \leq 0.05)$ positive and negative trends. The ANOVA assumptions of normality and homoscedasticity were checked and confirmed.

\section{Results}

The oil concentrations in the water and sediment samples are presented in Table 1. The oil concentrations found within the sediment remained relatively consistent at the different sites during the course of the study, with a clear spike in concentrations during the second survey. The site at the source of the oil spill had the highest average oil concentration in the sediment during the course of the study (site $1=\sim 25.73 \mathrm{mg} / \mathrm{kg}$ ) compared to the other sites where the concentrations ranged between $\sim 1.6$ and $\sim 5.55 \mathrm{mg} / \mathrm{kg}$. The oil concentration at site 1 showed a significant negative trend $(p \leq 0.05)$ over time. Generally, the sunflower oil concentration in the water column decreased after the initial post-spill survey, after which it increased again during the third survey (Table 1). These concentrations then steadily decreased during the course of the study. Site 1 also had the highest average oil content in the water column during the course of the study $(\sim 3.75 \mathrm{mg} / \mathrm{L})$, whereas the rest of the sites ranged between $\sim 1.04$ and $\sim 2.54 \mathrm{mg} / \mathrm{L}$. In spite of these differences, measured oil contents between the sites were not statistically significant according to the ANOVA results $(p=0.406)$. The average BOD levels (165 mg/L) were much higher over the study period in the water column of site 5 in comparison to sites $1,2,3$, and 4 where BOD concentrations were much lower $(61,72,81$, and $96 \mathrm{mg} / \mathrm{L})$.

The abiotic parameters measured within the sediment and water column showed different spatial and temporal trends throughout the study period (Fig. 2). The $\mathrm{pH}$ levels at all sites increased initially during the second post-spillage survey, after which it decreased again during the consecutive trips and remained relatively consistent and only increased again during the last survey. Overall, the average $\mathrm{pH}$ levels at the different sites varied between $\sim 7.5$ at site 1 and $\sim 9.3$ at site 5 . The $\mathrm{pH}$ levels measured at these two sites were also found to be significantly different $(p \leq 0.05)$. Overall, sites 1 and 2 had lower $\mathrm{pH}$ levels, compared to the rest of the sites, during the first couple of surveys.

Although a slight increase in electrical conductivity was noticed as the study progressed, no clear temporal trend was observed, and in general, the sites had similar conductivity levels which generally remained below $1,000 \mu \mathrm{S} / \mathrm{cm}$. This threshold was only exceeded at some sites during the last survey. Dissolved oxygen concentrations decreased at all of the sites after the initial postspill survey, after which it remained relatively constant. However, a spike in dissolved oxygen concentrations was noticed during the fourth survey at each of the respective sites, but the degree of the spike varied between the different sites. Silica concentrations showed no clear temporal trend, and the average concentrations fluctuated between $3.3 \mathrm{mg} / \mathrm{L}$ at site 4 and $5.3 \mathrm{mg} / \mathrm{L}$ at site 1 . These minimum and maximum concentrations recorded at the respective sites were found to be significantly different $(p \leq 0.05)$.

Total phosphate and total nitrogen concentrations decreased at the sites closest to the source of the oil spill (sites 1 and 2) from the initial post-spill survey, after which total phosphate and total nitrogen concentrations remained relatively constant at all of the sites throughout the course of the study. The total nitrogen and total phosphate concentrations at site 2 and site 5 showed a significant negative trend $(p \leq 0.05)$ over time. Sites 1 and 2 had higher total nitrogen and total phosphate concentrations during the 
Table 1 Oil concentrations in the water and sediment samples collected during the study at the five selected sampling sites

\begin{tabular}{cccllll}
\hline Sites & October 2008 & January 2009 & April 2009 & June 2009 & August 2009 & October 2009 \\
\hline \multicolumn{2}{c}{ Oil concentration in water (mg/L) } & & & & \\
1 & 7.5 & 1.25 & 6.125 & 4.375 & 2.75 & 0.5 \\
2 & 2.64 & 0.125 & 2.125 & 4.625 & 3 & 0.125 \\
3 & 9.5 & 0.125 & 0.825 & 3 & 1 & 0.625 \\
4 & 6.75 & 0.125 & 1.625 & 4 & 2.625 & 0.125 \\
5 & 0.25 & 0.125 & 0.625 & 3.875 & 1.25 & 0.125 \\
Oil concentration in sediment $(\mathrm{mg} / \mathrm{kg})$ & & & & \\
1 & 20.4 & 117.5 & 7.5 & 3.875 & 4.625 & 0.5 \\
2 & 0.005 & 5 & 2.125 & 3.5 & 1.875 & 0.625 \\
3 & 0.065 & 27.5 & 0.375 & 3.375 & 1.375 & 0.625 \\
4 & 0.085 & 22.5 & 1.375 & 2.25 & 3.875 & 0.625 \\
5 & 0.15 & 2.5 & 0.625 & 4.25 & 1.25 & 0.825 \\
\hline
\end{tabular}

first post-spillage survey when compared to the other sites. The chlorophyll $a$ concentrations decreased at sites 3, 4, and 5 during consecutive field surveys, after which it remained consistent. The sites closest to the origin of the oil spill had the lowest chlorophyll $a$ concentrations, namely, site $1=\sim 4.2 \mu \mathrm{g} / \mathrm{L}$ and site $2=\sim 4.8 \mu \mathrm{g} / \mathrm{L}$.

Spatial and temporal changes in macroinvertebrate diversity and richness at each site are presented in Fig. 3. No temporal trend could be observed. The highest average diversities $\left(H^{\prime}=\sim 1.98\right)$ and richness ( $d=\sim 1.54$ ) during the course of the study was noticed at site 3 , whilst the lowest diversity $\left(H^{\prime}=\sim 1.16\right.$ and $1.19)$ and richness $(d=\sim 1.53$ and 1.88) was found at site 2 and site 1 , respectively.

Figure 4 is an ordination plot and presents the changes in the aquatic macroinvertebrate community structures, with the changes in the abiotic variables overlain. From this plot, it can be deduced that there is a strong relationship between the increase in oil pollution (both in the water and sediment) with the increase in Chironomidae and Pshycodidae abundances. The data generated showed that the increase in total nitrogen and total phosphate occurred along with the increase in oil pollution. These increases resulted in the grouping together of most of site 1's and site 2's early sampling points (namely October 2008, January 2009 and April 2009), indicating that these sites, especially site 1 , were the most badly affected by the oil pollution. It can also be observed that an increase in oil concentrations resulted in a decrease in $\mathrm{pH}$, as well as chlorophyll $a$ concentrations. This is due to the increase in these concentrations in an opposite direction to that of the oil concentrations.

Inhibitory or stimulatory mechanisms in the $R$. subcapitata algal bioassay showed that algal growth was adversely affected by the sunflower oil in the wetland water (Fig. 5). All sampling sites (1-5) showed a decrease in chlorophyll $a$ and $b$ concentrations (3.01-1.75 and 2.21-1.03 $\mu \mathrm{g} / \mathrm{L}$, respectively) as compared to the average of the control sample (chl $a=4.78 \mu \mathrm{g} / \mathrm{L}$ and chl $b=1.77 \mu \mathrm{g} / \mathrm{L}$ ) over the study period. In the $D$. pulex bioassay, mortalities were noticeable in the spring 2008 and summer 2009 seasons with \pm 85 and $\pm 70 \%$ survival rate after $48 \mathrm{~h}$ of treatment in comparison to $100 \%$ survival rate in the control test (Fig. 6). However, in the succeeding seasons (April 2008 to October 2009), no effect was observed on the biotest species as compared to the control test. The survival rates of $P$. acuta in the water samples collected at the sampling sites showed no adverse effect on the specimens in comparison to the control test during all seasons as no mortality or immobility of $P$. acuta was found in all test and control containers during the exposure time (100\% survival) (Fig. 6). Figure 7 illustrates the response of the biotest species $S$. punctata to the sunflower oil-contaminated water samples of the five different sites. There was no reduction observed over the $72 \mathrm{~h}$ of incubation period in S. punctata frond's growth as compared to control plants. Generally, the sensitivity rates for all sampled wetland water of the sampling sites were in the following order: $R$. subcapitata $>D$. pulex $>$ $P$. acuta $>S$. punctata, with no difference between the last two tested species. 

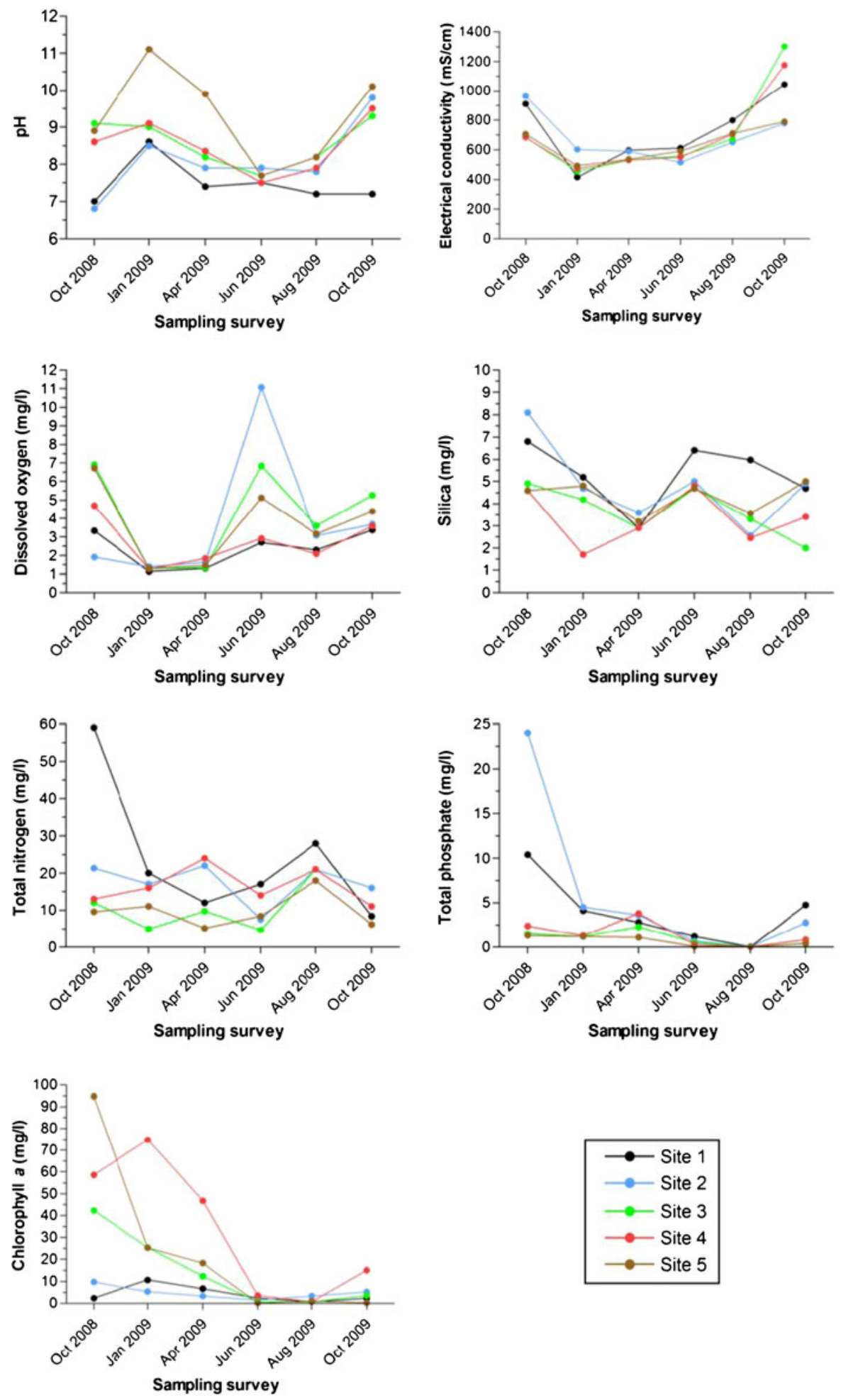

Fig. 2 Various chemical parameters measured throughout the 12-month monitoring period in the water column and sediment 

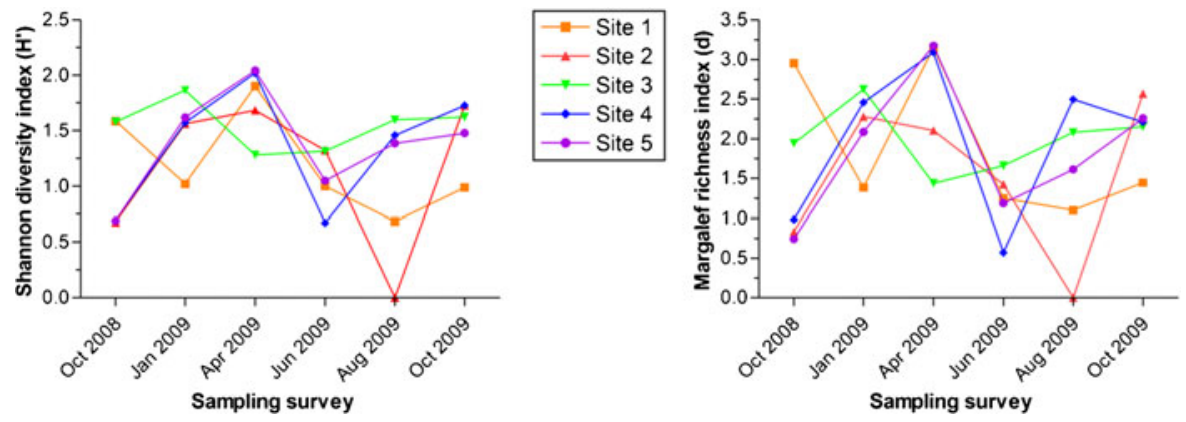

Fig. 3 The Shannon diversity index $\left(H^{\prime}\right)$ and Margalef richness index $(d)$ of the aquatic macroinvertebrate communities present at different sampling sites $(1-5)$

\section{Discussion}

Currently, there is little (if any) information available on the impacts of vegetable oil spills in freshwater wetlands. This is due to the fact that vegetable oil spills are not a "traditional" spill like crude oil, fuel oil, and other petroleum oils within water bodies (Oliveira and Keller 2001). Previously, incidents of vegetable oil spills have only been reported in rivers, salt marshes, and marine environments. Studies carried out on these events indicated that the spilled oil may undergo polymerization and persists for up to 6 years within the
Fig. 4 A redundancy analysis plot showing the similarity between sites based on macroinvertebrate abundance data with water quality variables superimposed (the percentage variance explained on the first axis is $34.9 \%$ and on the second axis is $20.4 \%$, with a total explained variance of $55.3 \%$ and $R^{2}=0.952$ )

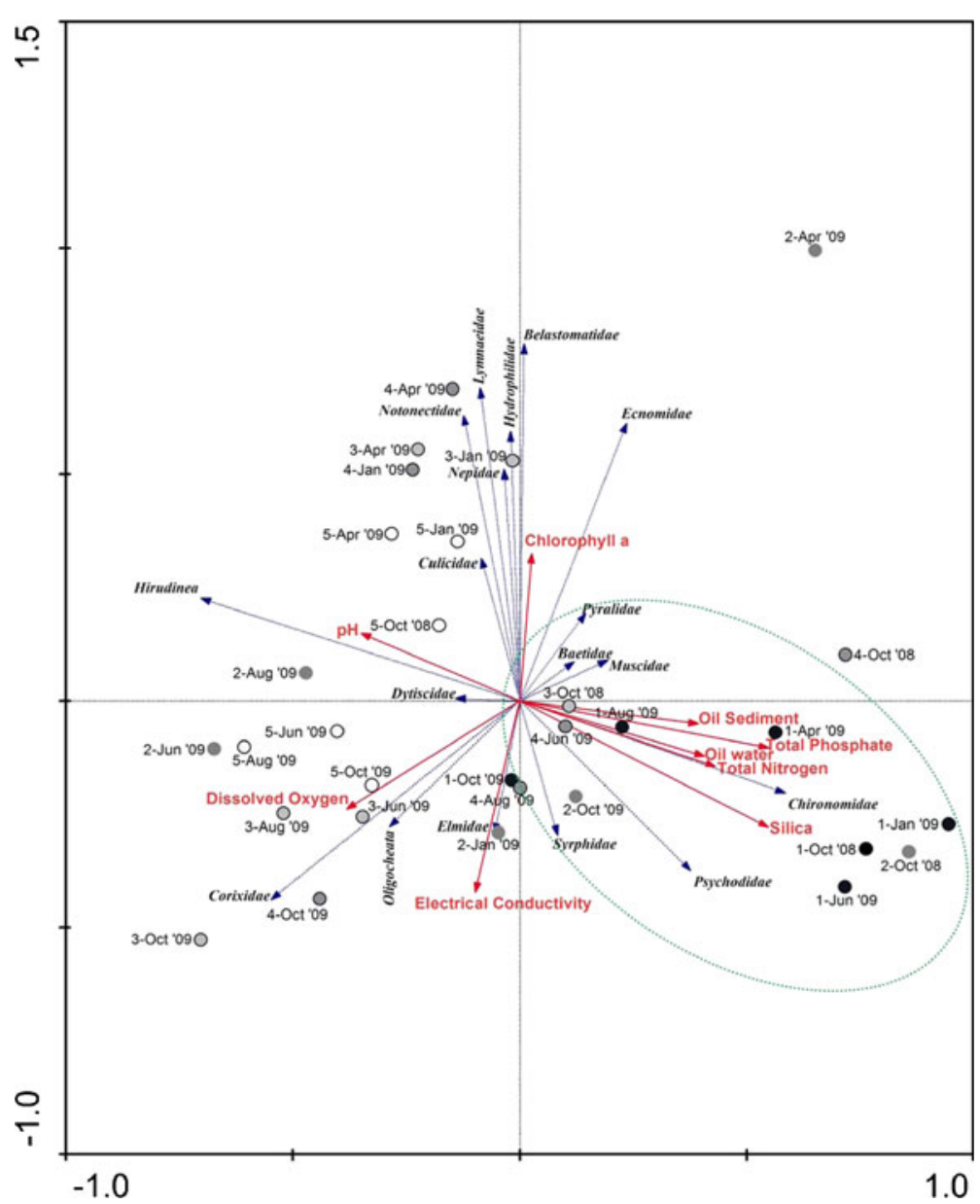


Fig. 5 Chlorophyll contents from $R$. subcapitata biotest in response to sunflower oil contamination. Seasonal variation in chlorophyll concentrations: 1 control, 2 spring (October 2008), 3 summer (January 2009), 4 autumn (April 2009), 5 winter (June 2009), and 6 spring (August and October 2009). Letters $a$ and $b$ indicate significant differences to the control test $(P<0.05)$

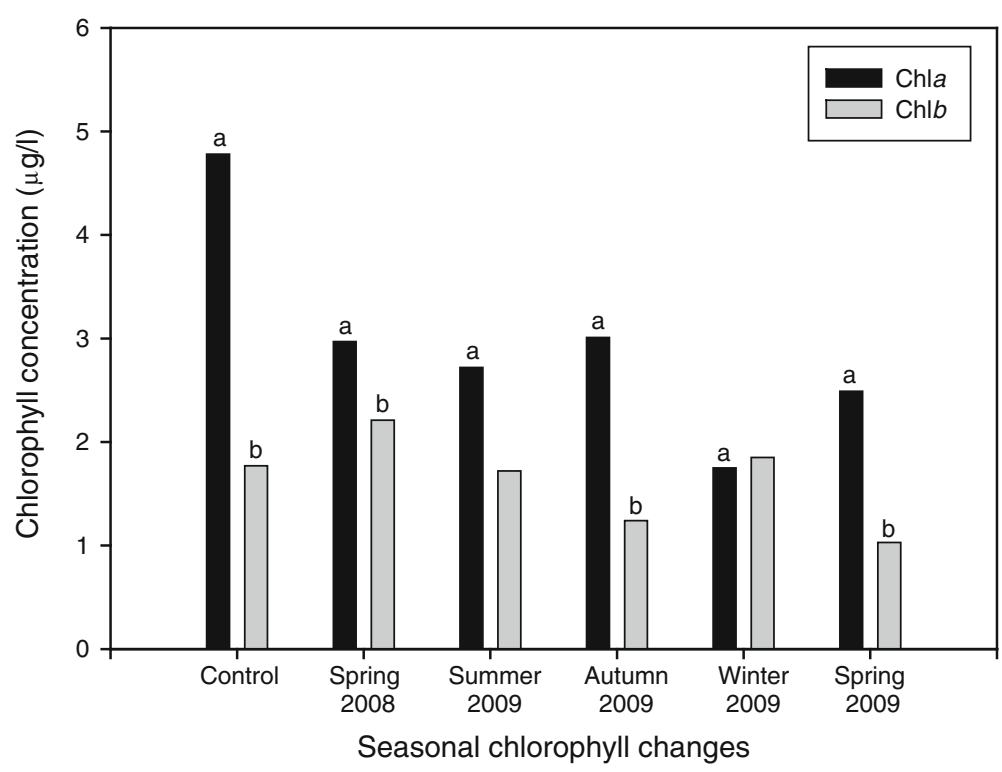

environment (Mudge 1997). Thus, the physical properties of vegetable oils, as well as their environmental fate and effect, appear to be very similar to that of petroleum oils (Crump-Wiesner and Jennings 1975). During this study, the oil concentrations measured in the water was high during the first post-spillage field survey but decreased during the second survey. This is inversely related to the oil concentrations measured in the sediment that was initially low but spiked during the second survey (see Table 1). This phenomenon was due to the oils that settled out onto the sediments (Mudge 1997; USEPA 1997) during the second survey.
Previous studies have demonstrated the feasibility of removing floating vegetable oil from the water surface by using clay to promote sedimentation as dense oilmineral aggregates (Wincele et al. 2004). Considering that the average water depth over the study period was only $20 \mathrm{~cm}$ and that the sediment composition was mainly made up of clay, we hypothesize herein that the wind re-suspended the clayey sediments, plunging the suspended oil into the bottom during the second survey (January 2009). After that, the anaerobic biodegradation of vegetable oil in sediments began ( $\mathrm{Li}$ et al. 2001, 2005; Li and Wrenn 2004), explaining the drop in
Fig. 6 Toxicity response among multispecies biotests during four seasons of the study. Sampling dates: spring (October 2008), summer (January 2009), autumn (April 2009), winter (June 2009), spring (August and October 2009). Letter $a$ indicates significant difference with the control test $(P<0.05)$

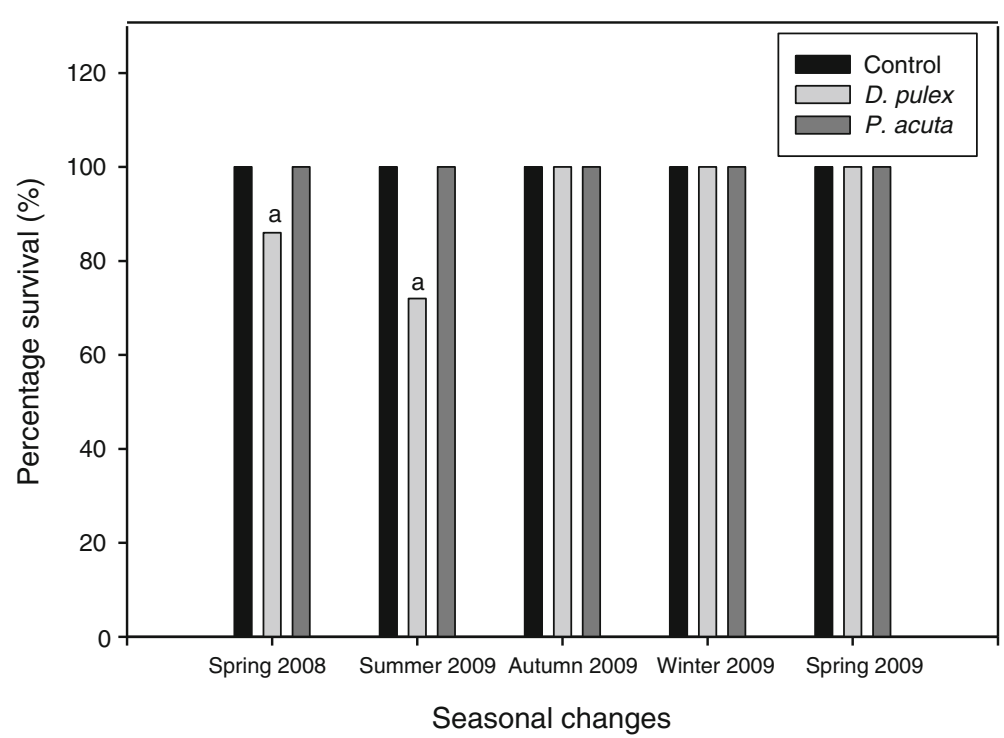


Fig. 7 Toxicity response after 24,48 , and $72 \mathrm{~h}$ of incubation with undiluted wetland water (100\% concentration of oil-contaminated water) of the five sampling sites. No significant differences with control test were found $(P>0)$

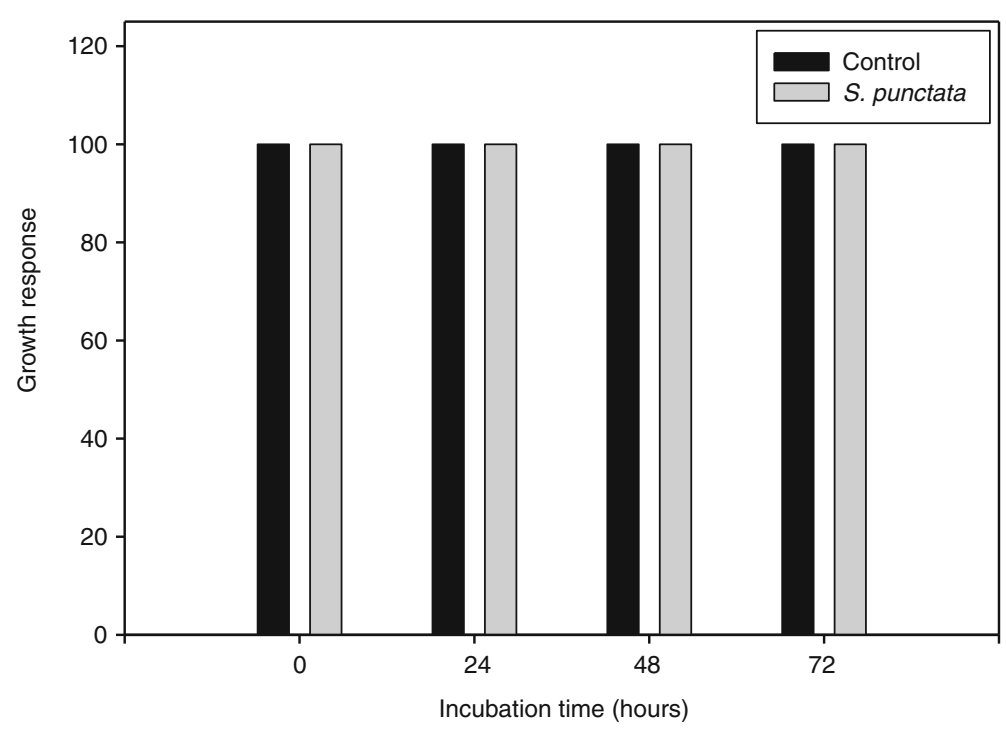

oil concentration in sediments over time (see Table 1). Although clay can effectively transfer vegetable oil from the water to sediments where anaerobic degradation of vegetable oil can occur, the metabolic intermediates of degradation may be toxic to microorganisms (Cherrington et al. 1991), mussels (Mudge 1995), and amphipods (Li et al. 2007). Transient sediment toxicity was also observed during the anaerobic biodegradation of vegetable oil in freshwater sediments ( $\mathrm{Li}$ and Wrenn 2004). This fact could have strong ecological consequences for the macroinvertebrate composition in this study, where Chironomidae (indicators of pollution) were dominant in the most polluted sites (Fig. 4). Overall, the oil concentrations in the water and sediment decreased during the course of the study, although some fluctuations do occur, with the concentrations in the sediment having a negative trend over time. These results indicate that most of the spilled oil settled out onto the sediment relatively quickly after the spillage has occurred from where it degraded over time.

The initial increase in oil concentration measured in the water column corresponded to the initial increase in total nitrogen and total phosphate concentrations (Table 1 and Fig. 2), which correlate with the multivariate analysis of the abiotic variables (Fig. 4). The sites closest to the source of the spillage, namely, sites 1 and 2 , had the most noticeable increase in total nitrogen and total phosphate during the initial survey but also had the lowest chlorophyll $a$ concentrations. This indicates that vegetable oil increases the total nitrogen and total phosphate concentrations in the water column and also, as in the case of crude oil, inhibits the growth of microalgae (Fabregas et al. 1984), which resulted in the decreased concentrations of chlorophyll $a$. The $\mathrm{pH}$ levels found at sites 1 and 2 were also low during the initial survey, when compared to the other sites, but appeared to stabilize and follow a similar trend to that observed at the other sites during the course of the study. In the case of the $\mathrm{pH}$ values at site 1 , which was the closest to the spillage, and site 5, which was the farthest from the spillage, the values were found to vary significantly. This corresponds with the decrease in chlorophyll $a$ observed at these sites as increased photosynthesis of the aquatic vegetation (including algae) results in an increase of the $\mathrm{pH}$ in standing water (Barkay et al. 1989; Mason et al. 1995; DWAF 1996; Ravichandran 2004). No clear relationship could be observed between the temporal changes in vegetable oil concentration and that of electrical conductivity, dissolved oxygen, and silica concentrations. The observed changes may be a result of seasonal variability as there would be an increase in productivity during certain seasons, which in turn will impact on certain abiotic factors, for example, dissolved oxygen, etc. (Dallas and Day 1993). However, depletion of dissolved oxygen from the water column has been reported by other authors (Calanog et al. 1999). The higher BOD values measured at sampling site 5 was possibly due to the microbial processes utilizing the oxygen from the water column during the degradation processes of the sunflower oil.

The sunflower oil-contaminated freshwater showed adverse effects on the tested specimens of $D$. pulex at 
two sampling sites ( 1 and 2), while at sites 3 to 5 no toxicity was observed during the entire study period. This may indicate that the toxicity of the sunflower oil concentrations at sites 1 and 2 were above the species' threshold level in comparison to the control. The species $R$. subcapitata showed significantly different toxicity effects after exposure for $72 \mathrm{~h}$ to the water samples from the wetland as measured chlorophyll $a$ and $b$ concentrations in comparison to the control. According to Baun et al. (2000), the use of this species is regarded as the most sensitive bioassay test of pollutants in water followed by the daphnids and duckweed bioassays. Masojídek et al. (2011) reported that the mechanisms causing the biotest's sensitivity were strongly related to the processes of adaptation of $R$. subcapitata to the experimental water samples. The results of this bioassay showed significant differences amongst the seasons (October 2008, January 2009, April 2009, June 2009, August 2009, and October 2009) in chlorophyll $a$ concentrations as compared to the control sample. From the data, it was evident that sunflower oil toxicity was at a cellular level, which possibly affected the pathway of photosynthesis by affecting chlorophylls $a$ and $b$ (Baryla et al. 2001). However, the $P$. acuta (snail) biotest showed no susceptibility or stress and mortality to the sunflower oil-impacted water samples during the incubation period at all sampling sites (1-5) in comparison to the control sample. Greer et al. (2001) reported in their study that snail growth in oil-impacted environments could be related to the reduction of petrochemical toxicity and an increase in a microorganism's growth following nutrient amendment. In the case of sunflower oil pollution, there was no previous published information focusing on the assessment of its toxicity to the different life stages of aquatic snails. It was evident from the result of the battery of four different bioassays that toxicity effects differed between trophic levels since various forms of biota differ in their sensitivity to toxicants. The latter observations were in relation with the data obtained in the field macroinvertebrate study, indicating that certain macroinvertebrate families were more tolerant to the adverse effects of sunflower oil than other families.

According to Dallas and Day (1993), water quality is one of the most important factors which influence an aquatic ecosystem's integrity as the distribution of aquatic freshwater organisms is controlled mainly by water quality characteristics, including dissolved oxygen, acidity, and nutrient content. Aquatic macroinvertebrates are an important component in aquatic food webs, linking organic matter and nutrients with higher trophic levels (Yoshimura et al. 2006). Various environmental variables are known to influence macroinvertebrate assemblages (Collier 1995; Wright 1995) and result in changes in their density and/or biomass (Idyll 1943; O'Connel and Campbell 1953). From Fig. 4, it can be deduced that at sites 1 and 2, located near the source of the spillage, a good correlation exists between the relative dominance of Chironomidae and Psychodidae, and to a lesser extent Syrphidae, and the increase in oil within the sediment and water during the initial post-spillage field surveys. These changes highlight modifications in the composition of dominant taxa (Leland et al. 1989), for example, shifts from sensitive to less sensitive species (Norris et al. 1982; Clements 1994).

The relationship illustrated in Fig. 4, where an increase in Chironomidae and Psychodidae was observed along with an increase in oil concentrations in the sediment and water, indicated their relative tolerance to this type of pollution and their ability to thrive under these circumstances. These findings confirm previous studies that noted that Chironomidae are generally linked to low dissolved oxygen concentrations and high organic matter (Ocon et al. 2008). Among all the macroinvertebrate taxa, Chironomidae is one of the richest groups of species that are found in freshwater habitats (Cranston 1995). Because they spend most of their developmental time in the sediment surface, where they remain exposed to different toxicants, as well as have a short life cycle, Chironomidae are well known as indicators of pollution (e.g., Rosenberg 1992). In general, it is recognized that taxa assemblages tend to be mostly dominated by a few species in polluted sites (e.g., Astin 2006) and that Chironomidae species can greatly contribute to this increased dominance (Camargo et al. 2004). Because of that and due to the difficulty of identifying the species in their larval stage, they are often considered in biotic indices at a family level (Marziali et al. 2006). On the other hand, when continuously exposed to stress or pollution, late instars of some chironomid larvae frequently develop deformities in the mouth parts. These deformities are a reflection of environmental pollution (Watanabe et al. 2000; Martinez et al. 2004). This means that Chironomidae, which in the present study showed a clear relationship with more polluted sites (Fig. 4), have a great potential to be used as bioindicators, either in biotic indices or through the analysis of deformities. Thus, knowing the effect of vegetable oil pollution on 
Chironomidae becomes a topic of great importance for future biomonitoring studies. The results found herein also infer a similar environmental fate of vegetable oil pollution to that of petroleum as Oberholster et al. (2005) also found higher abundances of Chironomidae in a petroleum-contaminated environment.

The fact that Psychodidae increased its density at the more polluted sites (sites 1 and 2) presents an ecological problem with direct implications for human health as species of this family are vectors of the disease leishmaniasies. The Leishmania parasites develop to an infective form inside the gut of Psychodidae and are injected together with saliva into a mammalian host during blood feeding (Kato et al. 2006). Another taxon that also showed a relatively good relationship with that of the oil concentrations was Syrphidae. This family is known to thrive well in shallow polluted waters that permit the tip of the extended caudal respiratory tube to be projected just above the surface (James 1979; Arimoro et al. 2007). On the other hand, Oligochaeta did not show any relationship with increasing vegetable oil pollution, although they are known to thrive in polluted environments. These macroinvertebrates appeared to be more present at the less impacted, more oxygenated sites. Aquatic macroinvertebrates are especially sensitive to organic pollution (Assmuth and Penttilä 1995) and are capable of integrating these effects during their lifetime (Ten Brink and Woudstra 1991). Macroinvertebrate assemblages dominated by high numbers of a single macroinvertebrate family are generally indicative of stressed ecosystems as these organisms are less sensitive to various impacts than any other major macroinvertebrate taxa (Warwick and Clarke 1993). Thus, from the data generated, it was evident that Chironomidae and Pshycodidae can be used as indicator organisms to determine the impacts of vegetable oil spills on freshwater wetlands. Furthermore, changes in the assemblage of these indicator taxa can be a useful management tool for remediation measures during post-spill conditions.

\section{Conclusions}

Vegetable oil pollution in freshwater wetlands has, to our knowledge, not been reported previously, and its environmental fate and effects are relatively unknown. Spatial and temporal changes in selected abiotic factors have been observed, and as a result, total nitrogen, total phosphate, BOD, and chlorophyll $a$ concentrations, as well as $\mathrm{pH}$ levels, were observed to be affected by an increase in vegetable oil pollution. A shift in the macroinvertebrate assemblages studied at the selected sites was noticed, with a clear increase in tolerant macroinvertebrate taxa noticed at the sites that were most impacted (sites 1 and 2). As a result, two core taxa, namely, Chironomidae and Psychodidae, and to a lesser extent Syrphidae, were identified as potential indicators of vegetable oil contamination within a freshwater wetland. These indicator taxa can be a useful management tool to determine if freshwater wetlands impacted by vegetable oil spills are recovering after employing remediation measures. An integrated assessment gathers complementary lines of evidence of ecological effect/ecological integrity of a system. We conclude that, given the realistic nature of the in situ studies, they should be considered in this strategy.

Acknowledgments The authors would like to thank the National Research Foundation and the University of Pretoria for their financial support.

\section{References}

APHA, AWWA \& WPCF. (1992). Standard methods for the examination of water and wastewater (19th ed.). Washington, DC: American Public Health Association, American Water Works Association and Water Pollution Control Federation.

Arimoro, F. O., Ikomi, R. B., \& Iwegbue, C. M. A. (2007). Water quality changes in relation to Diptera community patterns and diversity measured at an organic effluent impacted stream in the Niger Delta, Nigeria. Ecological Indicators, 7, 541-552.

Assmuth, T., \& Penttilä, S. (1995). Characteristics, determinants and interpretations of acute lethality in Daphnids exposed to complex waste leachates. Aquatic Toxicology, 31, 125-141.

Astin, L. A. (2006). Data synthesis and bioindicator development for non-tidal streams in the interstate Potomac River basin, USA. Ecological Indicators, 6, 664-685.

Barkay, T., Liebert, C., \& Gillman, M. (1989). Environmental significance of the potential for mer(Tn21)-mediated reduction of $\mathrm{Hg}^{2+}$ to $\mathrm{Hg}^{0}$ in natural waters. Applied and Environmental Microbiology, 55, 1196-2002.

Baryla, A., Carrier, P., Franck, F., Coulomb, C., Sahut, C., \& Havaux, M. (2001). Leaf chlorosis in oilseed rape plants (Brassica napus) grown on cadmium-polluted soil: causes and consequences for photosynthesis and growth. Planta, 212, 696-709.

Baun, A., Jensen, S. D., Bjerg, P. L., Christensen, T. H., \& Nyholm, N. (2000). Toxicity of organic chemical pollution in groundwater downgradient of a landfill (Grindsted, Denmark). Environmental Science and Technology, 34, 1647-1652. 
Blaise, C., Gagné, F., Chévre, N., Harwood, M., Lee, K., Lappalainen, J., et al. (2004). Toxicity assessment of oilcontaminated freshwater sediments. Environmental Toxicology, 19, 267-273.

Bury, R. B. (1972). The effects of diesel fuel on a stream fauna. California Fish and Game, 58, 291-295.

Cairns, J., McCormick, P. V., \& Niederlehner, B. R. (1993). A proposed framework for developing indicators of ecosystem health. Hydrobiologia, 263, 1-44.

Calanog, S. A., Chen, J. Y., \& Toia, R. F. (1999). Preliminary evaluation of potential impacts of non-petroleum oils on the aquatic environments. Proceedings of the 1999 International Oil Spill Conference. Washington, DC: American Petroleum Institute.

Camargo, J. A., Alonso, A., \& De La Puente, M. (2004). Multimetric assessment of nutrient enrichment in impounded rivers based on benthic macroinvertebrates. Environmental Monitoring and Assessment, 96, 1-3.

Cherrington, C. A., Hinton, M., Mead, G. C., \& Chopra, I. (1991). Organic acids: chemistry, antibacterial activity and practical applications. Advances in Microbial Physiology, 32, 87-108.

Chutter, F. M. (1998). Research on the rapid biological assessment of water quality: Impacts in streams and rivers. WRC Report No. 422/1/98. Pretoria: Water Research Commission.

Clarke, K. R., \& Gorley, R. N. (2006). Primer v6: User manual or tutorial. Plymouth: PRIMER-E.

Clements, W. H. (1994). Benthic invertebrate community responses to heavy metals in the upper Arkansas River basin, Colorado. Journal of the North American Benthological Society, 13, 30-44.

Clément, B., Devaux, A., Perrodin, Y., Danjean, M., \& GhidiniFatus, M. (2004). Assessment of sediment ecotoxicity and genotoxicity in freshwater laboratory microcosms. Ecotoxicology, 12, 323-333.

Collier, K. J. (1995). Environmental factors affecting the taxonomic composition of aquatic macroinvertebrate communities in lowland waterways of Northland, New Zealand. New Zealand Journal of Marine and Freshwater Research, 4, 453-465.

Cornish, A., Battersby, N. S., \& Watkinson, R. J. (1993). Environmental fate of mineral, vegetable and transesterified vegetable oils. Pesticide Science, 37, 173-178.

Cranston, P. S. (1995). Introduction. In P. D. Armitage, P. S. Cranston, \& L. C. V. Pinder (Eds.), The Chironomidae: Biology and ecology of non-biting midges. London: Chapman and Hall.

Crump-Wiesner, H. J., \& Jennings, A. L. (1975). Properties and effects of nonpetroleum oils. Proceedings of 1975 Conference on Prevention and Control of Pollution. Washington, DC: American Petroleum Institute.

Dallas, H. F., \& Day, J. A. (1993). The effect of water quality variables on riverine ecosystems: A review. WRC report no. TT 61/93. Pretoria: Water Research Commission.

De Klerk, A. R., \& Wepener, V. (2011). The influence of biotope and sampling method on the assessment of the invertebrate community structure in endorheic reed pans in South Africa. African Journal of Aquatic Science, 36, 67-74.

De la Rey, P. A., Taylor, J. C., Laas, A., Van Rensburg, L., \& Vosloo, A. (2004). Determining the possible application value of diatoms as indicators of general water quality: a comparison with SASS 5. Water SA, 30, 325-332.
Dickens, C. W. S., \& Graham, P. M. (2002). The South African Scoring System (SASS) version 5: rapid bioassessment method for rivers. African Journal of Aquatic Science, 27, $1-10$.

DWAF. (1996). South African water quality guidelines. Volume 7: Aquatic ecosystems (1st ed.). Pretoria: Department of Water Affairs and Forestry.

Fabregas, J., Herrero, C., \& Veiga, M. (1984). Effect of oil and dispersant on growth and chlorophyll a content of the marine microalga Tetraselmis suecica. Applied and Environmental Microbiology, 47, 445-447.

French-McCay, D. P. (2002). Development and application of an oil toxicity and exposure model, OilToxEx. Environmental Toxicology and Chemistry, 21, 2080-2094.

Frink, L. (1994). Statement on regulatory standards for the transportation of edible oil. Tri-State Bird Rescue and Research, 30.

Gesteira, G. J. L., Dauvin, J. C., \& Fraga, M. S. (2003). Taxonomic level for assessing oil spill effects on soft-bottom sublittoral benthic communities. Marine Pollution Bulletin, 46, 562-572.

Greer, C. W., Fortin, N., Roy, R., Whyte, L. G., \& Lee, K. (2001). Microbial population dynamics and degradation activity in response to a controlled oil spill on a freshwater wetland. Bioremediation Journal, 6, 2002.

Hauer, F. R., \& Lamberti, G. A. (2006). Methods in stream ecology (pp. 1-877). California, USA: Academic, San Diego.

Idyll, C. P. (1943). Bottom fauna of portions of the Cawichan River, B.C. Journal of the Fisheries Research Board of Canada, 6, 133-139.

James, A. (1979). The value of biological indicators in relation to other parameters of water quality. In A. James \& L. Evison (Eds.), Biological indicators of water quality. Chichester: Wiley-Interscience.

Kato, H., et al. (2006). High degree of conservancy among secreted salivary gland proteins from two geographically distant Phlebotomus duboscqi sand flies populations (Mali and Kenya). B.M.C. Genomics, 7, 226.

Leland, H. V., Fend, S. V., Dudley, T. L., \& Carter, J. L. (1989). Effects of copper on species composition of benthic insects in a Sierra Nevada, California, stream. Freshwater Biology, 21, 163-179.

Li, Z., Lee, K., \& Cobanli, S. E. (2007). Assessment of sediment toxicity during anaerobic biodegradation of vegetable oil using Microtox and Hyalella azteca bioassays. Environmental Toxicology, 22, 1-8.

Li, Z., Wincele, D. E., \& Wrenn, B. A. (2001). Anaerobic biodegradation of vegetable oil spills. Proceedings of the International Oil Spill Conference. Washington, DC: American Petroleum Institute.

Li, Z., \& Wrenn, B. A. (2004). Effects of ferric hydroxide on the anaerobic biodegradation kinetics and toxicity of vegetable oil in freshwater sediments. Water Research, 38, 38593868.

Li, Z., Wrenn, B. A., \& Venosa, A. D. (2005). Anaerobic biodegradation of vegetable oil and its metabolic intermediates in oil-enriched freshwater sediments. Biodegradation, 16, 341-352.

Lytle, D. A., \& Peckarsky, B. A. (2001). Spatial and temporal impacts of a fuel spill on stream invertebrates. Freshwater Biology, 46, 693-704. 
Margalef, R. (1951). Diversidad de species en las comunidades natuales. Publicaciones del Instituto de Biologia Aplicada, 6, 59-72.

Marques, M. M., \& Barbosa, F. (2001). Biological quality of waters from an impacted tropical watershed (middle Rio Doce basin, southeast Brazil), using benthic macroinvertebrate communities as an indicator. Hydrobiologia, 457, 69-76.

Martinez, E. A., Moore, B. C., Schaumloffel, J., \& Dasgupta, N. (2004). Teratogenic versus mutagenic abnormalities in chironomid larvae exposed to zinc and lead. Archives of Environmental Contamination and Toxicology, 47, 193-198.

Marziali, L., Lencioni, V., \& Rossaro, B. (2006). Chironomid species as indicators of freshwater habitat quality. Internationale Vereinigung fuer Theoretische und Angewandte Limnologie Verhandlungen, 29, 1553-1555.

Masojídek, J., Souček, P., Máchová, J., Frolík, J., Klem, J., \& Malý, J. (2011). Detection of photosynthetic herbicides: algal growth inhibition test vs. electrochemical photosystem $\Pi$ biosensor. Ecotoxicology and Environmental Safety, 74, 117-122.

Mason, R. P., Morel, F. M. M., \& Hemond, H. F. (1995). The role of microorganisms in elemental mercury formation in natural water. Environmental Science and Technology, 80, 775-787.

Merritt, R. W., \& Cummins, K. W. (1996). An introduction to the aquatic insects of North America (3rd ed.). Iowa: Kendall/ Hunt, Dubuque.

Mousavi, S. K., Primicerio, R., \& Amundsen, P.-A. (2003). Diversity and structure of Chironomidae (Diptera) communities along a gradient of heavy metal contamination in a subarctic watercourse. Science of the Total Environment, 307, 93-110.

MPCA. (2008). Macroinvertebrate community sampling protocol for depressional wetland monitoring sites. Biological monitoring program. Standard operating procedures. Minnesota: Minnesota Pollution and Control Agency.

Mudge, S. M. (1995). Deleterious effects from accidental spillage of vegetable oils. Spill Science and Technology Bulletin, 2, 187-191.

Mudge, S. M. (1997). Can vegetable oils outlast minerals oils in the marine environment? Marine Pollution Bulletin, 34, 213.

Mudge, S. M., Salgado, M., \& East, J. (1993). Preliminary investigations into sunflower oil contamination following the wreck of the M.V. Kimya. Marine Pollution Bulletin, $26,40-44$.

Musee, N., Oberholster, P. J., Sikhwivhilu, L., \& Botha, A.-M. (2010). The effects of engineered nanoparticles on survival, reproduction, and behaviour of freshwater snail, Physa acuta (Draparnaud, 1805). Chemosphere, 81, 1196-1203.

Nazarova, L. B., Pestryakova, L. A., Ushnitskaya, L. A., \& Hubberten, H.-W. (2008). Chironomids (Diptera: Chironomidae) in lakes of central Yakutia and their indicative potential for paleoclimatic research. Contemporary Problems of Ecology, 1, 335-345.

Norris, R. H., Lake, P., \& Swain, R. (1982). Ecological effects of mine effluents on the South Esk River, Tasmania: benthic invertebrates. Australian Journal of Marine \& Freshwater Research, 33, 789-809.

Oberholster, P. J., Blaise, C., \& Botha, A.-M. (2010). Phytobenthos and phytoplankton community changes upon exposure to a sunflower oil spill in a South African protected freshwater wetland. Ecotoxicology, 19, 1426-1439.

Oberholster, P. J., Botha, A.-M., \& Ashton, P. J. (2009). Appearance of new taxa: invertebrates, phytoplankton and bacteria in an alkaline, saline, meteorite crater lake, South Africa. Fundamental and Applied Limnology, 174, 271-282.

Oberholster, P. J., Botha, A.-M., \& Cloete, T. E. (2005). Using a battery of bioassays, benthic phytoplankton and the AUSRIVAS method to monitor long-term coal tar contaminated sediment in the Cachela Poudre River, Colorado. Water Research, 39, 4913-4924.

Ocon, C. S., Capítulo, A. R., \& Paggi, A. C. (2008). Evaluation of zoobenthic assemblages and recovery following petroleum spill in a coastal area of Río de la Plata estuarine system, South America. Environmental Pollution, 156, 82-89.

O'Connel, T. R., \& Campbell, R. S. (1953). The benthos of Black River and Clearwater Lake, Missouri. University of Missouri Studies, 26, 25-41.

Oliveira, B. M., \& Keller, K. (2001). Addressing the challenges of freshwater spills. International Oil Spill Conference Proceedings, 1, 267-270.

Porra, R. J., Thompson, W. A., \& Kriedemann, P. E. (1989). Determination of accurate extinction coefficient and simultaneous equations for assaying chlorophyll $a$ and $b$ extracted with four different solvents: verification of the concentration of chlorophyll standards by atomic absorption spectrometry. Biochimica et Biophysica Acta, 975, 384-394.

Poulton, B. C., Finger, S. E., \& Humphry, S. A. (1997). Effects of a crude oil on the benthic invertebrate community in the Gasconade River, Missouri. Archives of Environmental Contamination and Toxicology, 33, 268-276.

Rainio, J., \& Niemela, J. (2003). Ground beetles (Coleoptera: Carabidae) as bioindicators. Biodiversity and Conservation, 12, 487-506.

Ravichandran, M. (2004). Interactions between mercury and dissolved organic matter-a review. Chemosphere, 55, 319-331.

Rigger, D. (1997). Edible oils: are they really that different? Proceedings of the International Oil Spill Conference. Washington DC: American Petroleum Institute.

Rosenberg, D. M. (1992). Freshwater biomonitoring and Chironomidae. Netherlands Journal of Aquatic Ecology, 26, 101-122.

Shannon, C. E. (1948). A mathematical theory of communication. The Bell System Technical Journal, 26(379-423), 623-656.

Slabbert, L. (2004). Methods for direct estimation of ecological effect potential (DEEEP) (pp. 1-100). WRC Pretoria, South Africa: Water Research Commission report 1313/01/04.

Takahashi, M. A., Higuti, J., Bagatini, Y. M., Zviejkovski, I. P., \& Velho, L. F. M. (2008). Composition and biomass of larval chironomid (Insecta, Diptera) as potential indicator of trophic conditions in southern Brazil reservoirs. Acta Limnologica Brasiliensia, 20, 5-13.

Ten Brink, B. J. E., \& Woudstra, J. H. (1991). Towards an effective and rational water management: the aquatic outlook project - integrating water management, monitoring and research. European Water Pollution Control, 1, 20-27.

Thorp, J. H., \& Covich, A. P. (2001). Ecology and classification of North American freshwater invertebrates (2nd ed., pp. 1-867). San Diego: Academic. 
Tripole, S., Conzalez, P., Vallania, A., Garbagnati, M., \& Mallea, M. (2006). Evaluation of impact of acid mine drainage on the chestry and the macrobenthos in the Carolina stream (San Luis-Argentina). Environitoring Monitoring Assessment, 114, 377-389.

USDOC \& NOAA. (1996). Injury assessment: Guidance document for natural resources damage assessment under the oil pollution act of 1990. Damage assessment and restoration program. Maryland: United States Department of Commerce, National Oceanic and Atmospheric Administration.

USEPA. (1997). Oil pollution prevention; non-transportation related onshore facilities. Federal Register. United States Environmental Protection Agency, 62, 54508-54543.

Van Dam, R. A., Camilleri, C., \& Finlayson, C. M. (1998). The potential of rapid assessment techniques as early warning indicators of wetland degradation: a review. Environmental Toxicology and Water Quality, 13, 297-312.

Vujević, M., Vidaković-Cifrek, Z., Tomić, M., \& Regula, I. (2000). Calcium chloride and calcium bromide aqueous solutions of technical and analytical grade in Lemna bioassay. Chemosphere, 41, 1535-1542.

Warwick, R. M., \& Clarke, K. R. (1993). Comparing the severity of disturbance: a meta-analysis of marine macrobenthic community data. Marine Ecology Progress Series, 92, 221-231.

Watanabe, N. C., Harada, S., \& Komai, Y. (2000). Long-term recovery from mine drainage disturbance of a macroinvertebrate community in the Ichi-kawa River, Japan. Hydrobiologia, 429, 171-180.

Wincele, D. E., Wrenn, B. A., \& Venosa, A. D. (2004). Sedimentation of oil mineral aggregates for remediation of vegetable oil spills. Journal of Environmental Engineering, 130, 50-58.

Wright, J. F. (1995). Development and use of a system for predicting the macro-invertebrate fauna in flowing waters. Australian Journal of Ecology, 20, 181-197.

Wu, J., Fu, C., Liang, Y., \& Chen, J. (2004). Distribution of the meiofaunal community in a eutrophic shallow lake of China. Archives of Hydrobiology, 159, 555-575.

Yoshimura, C., Tockner, K., Omura, T., \& Moog, O. (2006). Species diversity and functional assessment of macroinvertebrate communities in Austrian rivers. Limnology, 7, 63-74.

Zoun, P. E. F., Baars, A. J., \& Boshuizen, R. S. (1991). A case of seabird mortality in the Netherlands caused by spillage of nonylphenol and vegetable oils, winter 1988/1989. Sula, 5, 101-103. 